\title{
BMJ Open The mental health of US Black women: the roles of social context and severe intimate partner violence
}

\author{
Krim K Lacey, ${ }^{1}$ Regina Parnell, ${ }^{2}$ Dawne M Mouzon, ${ }^{3}$ Niki Matusko, ${ }^{4}$ Doreen Head, ${ }^{2}$ \\ Jamie M Abelson, ${ }^{4}$ James S Jackson ${ }^{4}$
}

To cite: Lacey KK, Parnell R, Mouzon DM, et al. The mental health of US Black women: the roles of social context and severe intimate partner violence. BMJ Open 2015;5:e008415

doi:10.1136/bmjopen-2015008415

- Prepublication history for this paper is available online. To view these files please visit the journal online (http://dx.doi.org/10.1136/ bmjopen-2015-008415)

Received 14 April 2015 Revised 28 July 2015 Accepted 30 July 2015 CrossMark

${ }^{1}$ University of Michigan, Institute for Social Research, Program for Research on Black Americans, Ann Arbor, Michigan, USA

${ }^{2}$ College of Pharmacy and Health Sciences, Wayne State University, Detroit, Michigan, USA

${ }^{3}$ Rutgers, The State

University of New Jersey, Edward J. Bloustein School of Planning and Public Policy \& Institute for Health, Health Care Policy \& Aging Research, New Brunswick, New Jersey, USA

${ }^{4}$ University of Michigan, Institute for Social Research, Ann Arbor, Michigan, USA

Correspondence to

Krim K Lacey;

krimlacey@gmail.com

\section{ABSTRACT}

Objective: Black women continue to have rates of mental health conditions that can be negative for their well-being. This study examined the contribution of social and contextual factors and severe physical intimate partner violence on the mental health of US Black women (African-American and Caribbean Black). Setting: Data were largely collected via in-person community interviews at participants' homes.

Participants: We studied 3277 African-American and Black Caribbean women from the 2001-2003 National Survey of American Life (NSAL), the largest and most complete sample of Blacks residing in the USA.

Primary and secondary outcomes: Key outcomes included an array of psychiatric disorders based on the Diagnostic and Statistical Manual of Mental Disorders (DSM-IV).

Results: Bivariate results revealed noticeably high rates of any anxiety disorder, post-traumatic stress disorder, any substance disorder, alcohol abuse disorder, suicide ideation and attempts, and any overall mental disorder among African-American women relative to Caribbean Black women. Multiple social and contextual factors were associated with various mental disorders among both sets of Black women in multivariate models, with the most consistent associations found for severe physical intimate partner violence. Everyday discrimination was associated with anxiety disorders (95\% AOR=2.08 Cl 1.23 to 3.51), eating disorders (95\% AOR=2.69 $\mathrm{Cl} 1.38$ to 5.22$)$, and any disorder $(95 \% \mathrm{AOR}=2.18 \mathrm{Cl} 1.40$ to 3.40$)$, while neighbourhood drug problems contributed to $\operatorname{mood}(95 \% \mathrm{AOR}=1.19 \mathrm{Cl} 1.04$ to 1.36$)$, substance disorders (95\% AOR=1.37 $\mathrm{Cl} 1.11$ to 1.69$)$ and any disorder (95\% AOR=1.18 Cl 1.03 to 1.34).

Conclusions: Severe physical intimate partner violence, discrimination, and to a lesser extent, neighbourhood problems are important predictors of Black women's health, findings that inform intervention and clinical services tailored to meet the needs of Black women from diverse ethnic and cultural backgrounds.

\section{INTRODUCTION}

Black women continue to have high rates of health conditions that can negatively influence their well-being. ${ }^{1}{ }^{2}$ Although studies

\section{Strengths and limitations of this study}

- This study provides an understanding of prevalence rates of mental disorders within the Black population, and how they might differ among ethnic groups (ie, African-American vs Caribbean Blacks).

- The relative contributions of important neighbourhood characteristics and other social factors in the health of US Black women, particularly intimate partner violence, were ascertained.

- A standardised clinical assessment tool, based on the Diagnostic and Statistical Manual of Mental Disorders IV (DSM-IV) was used to assess mental health disorders.

- Possible temporal relationships between social factors and black women's mental health status could not be assessed due to the cross-sectional nature of the data.

have pointed to social and environmental factors as possible influences on Black women's health, many known, specific contributors (eg, neighbourhood context, intimate partner violence (IPV)) remain relatively underexplored in the literature. ${ }^{12}$

Most research on health issues facing women of colour has aggregated all Blacks into a single race category, masking the increasing diversity within this racial group. For example, the foreign-born population of Blacks increased more than threefold between 1980 and 2005. ${ }^{3}$ Almost half of all Black immigrants in the USA hail from countries in the Caribbean, with the highest shares from Jamaica, Haiti, and Trinidad and Tobago. ${ }^{4}$ Despite the greater recognition of an increasingly diverse US Black population resulting from growing immigrant populations from the Caribbean and African regions of the world, research on women's health focused on the meaning of this heterogeneity remains limited. This area of research could be important for policy and intervention formulation, given that 
Caribbean Blacks and African-Americans, for example, have different cultures and colonial histories that, while predisposing some women to negative health conditions, may alternatively serve as protective buffers for others.

\section{Exploring heterogeneity in health status among Black Americans}

Past mental health research often utilises racecomparative approaches to assess the relative differences in the mental health of Whites and Blacks. ${ }^{5}$ Although race-comparative research has been important in identifying both patterns of mental health disadvantage and resilience among Black and White women, newer research has recognised health differences within ethnic and immigrant groups. ${ }^{6}$ For instance, Williams et $a l^{7}$ note lower lifetime and past-year prevalence of any Diagnostic and Statistical Manual of Mental Disorder IV (DSM-IV) anxiety disorder, and any substance disorder among Black Caribbean women compared to African-American women, although there were no ethnic differences in any mood disorder between the two groups of women. These gender differences were reversed for men, with Caribbean Black men exhibiting a higher risk of psychiatric disorders than African-American men. Selection processes, resilience, high self-efficacy, healthier lifestyle choices and cultural practices are factors suggested as providing Caribbeans with protection from social and environmental conditions. ${ }^{7}$ Additional studies are necessary to better understand the health of ethnically and culturally diverse Black women residing in the USA, particularly how health is conditioned by social and contextual factors.

\section{Social-contextual factors affecting Black women's health}

Blacks residing in the USA have greater exposure to multiple domains of stressors, including but not limited to acute life events, financial stressors, and employment stressors. ${ }^{8}$ This stress exposure is often thought to be the primary cause underlying racial/ethnic health disparities that contribute to low health status among peoples of colour. $^{89}$

Given that health disparities persist even after controlling for socioeconomic status, scholars have pointed to the added effects of discrimination on the health of people of colour. ${ }^{10}$ Black women face discrimination that is both gender and race-based. ${ }^{11}{ }^{12}$ Studies have found a higher proportion of women than men experience these gender inequities. ${ }^{13}$ Perceived or direct exposure to discrimination can cause distress and adversely affect mental and physical health. ${ }^{10} \quad 12 \quad 14$ A study conducted on Black women living in Detroit found that unfair treatment was negatively associated with self-reported general health. ${ }^{15} 16$ Even after controlling for socioeconomic factors, perceived or direct exposure to discrimination has been associated with lower mental and physical health status.

Racial residential segregation is an important institutional mechanism underlying racial and ethnic health inequities. ${ }^{16} 17$ Various aspects of the built environment, including high-rise housing, housing quality, and neighbourhood deterioration, have also been linked to poor mental health outcomes. ${ }^{18}$ National data further indicates that stressful neighbourhoods, social isolation and community violence are associated with both depression and anxiety disorders. ${ }^{19}$ Black women are especially prone to these outcomes, given their low social standing, high poverty rates and history of occupying residences in resource-poor and segregated neighbourhoods. ${ }^{1} \quad 2 \quad 20$ African-American women who experience high levels of both community violence and IPV report more traumatic stress symptoms than those who are exposed to one type of violence or no violence at all. ${ }^{21}$

\section{Intimate partner violence}

IPV remains an important concern within Black communities and is a pervasive threat to women's health. ${ }^{1} 222$ For example, Black women experience IPV at comparably higher rates than women of other ethnic and racial groups. $^{23}{ }^{24}$ Physical acts of IPV have been associated with psychological consequences, such as depression, anxiety, post-traumatic stress disorder substance use and suicide. ${ }^{25-28}$ Some factors known to increase risk for violence include low socioeconomic status, socioenvironmental influences, drinking problems and illicit drug use. $^{2} 2124$ Couples who reside in neighbourhoods with high levels of poverty have a higher likelihood of experiencing IPV, with stronger associations for Black couples than White or Hispanic couples. ${ }^{23}$ However, methodological challenges have made it difficult to understand the contributions of interpersonal violence to Black women's mental well-being. ${ }^{22} 26$

\section{Research objectives}

We had two overarching goals in this research. First, using one of the largest and most representative samples of Black women residing in the USA, we build on past race-comparative epidemiological research on the prevalence of mental disorders among US Black women (African-American and Caribbean Black Women). We further evaluate the roles of social and contextual factors (neighbourhood characteristics, discrimination) and severe physical IPV on the mental health of US Black women.

\section{METHODS}

\section{Sample}

Data used to address the research aims are from the National Survey of American Life (NSAL), one of three surveys comprising the Collaborative Psychiatric Epidemiological Studies (CPES), and the largest and most detailed study on the health of Blacks living in the USA. $^{29}$ The NSAL is also the first national probability study of individuals of African descent with Caribbean roots. Multistage probability sampling methods were used to select respondents for the study. Face-to-face 
interviewing was the primary source of data collection, with a smaller percentage $(14 \%)$ collected through phone interviews. A total of 6082 respondents participated in the study including: 3570 African-Americans; 1623 Caribbean Blacks; and 891 non-Hispanic Whites. The overall response rate was $72.3 \%$. US Black women were the focus of this study.

\section{Measures}

Mental health

A modified version of the WHO Composite International Diagnostic Interview (WHO CIDI) defined by the fourth edition of the DSM-IV was used to assess lifetime mental health conditions. For each of the 17 disorders included, detailed questions assessed DSM diagnostic criterion, such as the presence of symptoms and clinically significant distress. The depression section asked 41 symptom questions, for example. Symptom criterion for major depressive episode requires that five (or more) symptoms have been present during the same 2-week period and represent a change from previous functioning; and, at least one of the symptoms is either depressed mood or loss of interest. The number and types of symptoms required varies by disorder (cut-off scores match the DSM requirements). By 'lifetime' disorder, we mean that criterion was met at any point in the subject's life.

In this paper, we combine disorders and report on six categories: mood disorders (eg, major depressive episode, dysthymia, major depressive disorder, bipolar); anxiety disorders (eg, panic, agoraphobia, generalised anxiety disorder, obsessive compulsive disorder, post-traumatic stress disorder); substance disorders (eg, alcohol abuse, alcohol dependence; drug abuse; drug dependence) and eating disorders (eg, anorexia, bulimia, binge eating). We report on 'any mental disorder' which is defined as at least one of the disorders previously listed, or a childhood or conduct disorder. We also report on suicidal ideation and attempts: "Have you ever seriously thought about committing suicide?" and "Have you ever attempted suicide?”

\section{Sociodemographic variables}

The demographic variables included in the analyses were age (18-24, 25-34, 35-49, 50-64, over 65) marital status (married, partnered, separated or divorced, widowed, never married), education (less than high school; high school graduate; some college; and college), income level (less than \$25 000; \$25 000-\$34 999; \$35 000-\$49 999; $\$ 50$ 000-74999; over $\$ 75000)$, and employment status (employed, not employed, not in the labour force). The two ethnic groups were: African-American and Caribbean Blacks. African-American comprised all individuals of African heritage, but without Caribbean roots. Caribbean Blacks were individuals with African heritage, but who also had Caribbean roots. These individuals also had parents or grandparents who were born in the Caribbean, or were from the list of Caribbean countries presented by interviewers. ${ }^{29}{ }^{30}$ A very small proportion of Blacks in the sample $(\mathrm{N}=169)$, men and women combined, were first generation from African countries.

\section{Contextual variables}

We focused on contextual factors, such as neighbourhood characteristics, drug and crime problems in neighbourhoods, and perceived everyday discrimination. Regarding crime problems in the neighbourhood, participants were asked, "How often are there problems with mugging, burglary, assaults or anything else like that in your neighbourhood." On a four-point Likert-scale, response options ranged from very often to never. Drug problem in the neighbourhood was determined by the question, "How much of a problem is the selling and use of drugs in your neighbourhood?" On a four-point Likert-scale, response options ranged from very serious to not at all. Everyday discrimination consisted of an index of 10 items: "You are treated with less courtesy than other people"; "You are treated with less respect than other people"; "You receive poorer service than other people at restaurants or stores"; "People act as if they think you are not smart"; 'People act as if they are afraid of you'; 'People act as if they think you are dishonest'; 'People act as if they are better than you are'; 'You are called names or insulted'; 'You are threatened or harassed'; and 'You are followed around in stores'. Responses were scored on a five-point Likert scale ranging from never to almost every day. The perceived discrimination items had an internal consistency of 0.89 . The index was then dichotomised such that $0=$ no experiences of discrimination and $1=$ one or more experiences of discrimination.

\section{Intimate partner violence}

Severe physical IPV was addressed with the question: "Have you ever been badly beaten up by a spouse or romantic partner (eg, yes/no)?" The IPV measure used in this study was compared to the National Comorbidity Survey-Replication (NCS-R) dichotomously defined severe partner violence measure from the severe physical violence subscales of the Conflict Tactics Scale (CTS) ${ }^{31} 32$ within the CPES, and was found to have fair agreement across two different estimates $(\mathrm{OR}=4.5, \mathrm{p}<0.001$; AUC $\geq 0.65){ }^{33}$

\section{Analytic strategy}

Bivariate associations between rates of disorders and race/ethnicity were designed-based statistic from crosstabulations. The percentages represent weighted prevalence rates based on the distribution of African-Americans and Caribbean Blacks in the population. The SEs were adjusted for the study's complex design. The Rao-Scott $\chi^{2}$ represents the design corrected measure of association between ethnic groups. Hierarchical logistic regression analysis was used to assess the influence of social and contextual contributors, as well as severe physical IPV on women's health outcomes in separate models. For each outcome, block 
one examined the contribution of the sociodemographic factors, including age, marital status, education, income, employment status, and race/ethnicity. Block two added the effects of contextual factors, such as discrimination, neighbourhood crime and drug problems, and block three assessed the added effects of severe physical IPV. For these analyses, we report OR estimates and 95\% CI adjusted for the study's complex design. Because of sample size concerns, we focused on 'any' mental health disorder within subcategories of mental conditions, as well as any overall mental health disorder in the multivariate analyses. We also addressed suicide ideation for similar reasons. The final analytic sample included 3277 African-American and Black Caribbean women. Missing values were excluded via listwise deletion. All analyses were conducted with Stata V.12, using the Taylor expansion approximation technique for calculating the design-based estimates of variance.

\section{RESULTS}

\section{Participants}

Of the women included in the study, approximately a third $(33.1 \%)$ were between the ages of 35-49, reported never having been married $(32.4 \%)$ and were only high school graduates $(36.2 \%)$. A half $(50.6 \%)$ of the women had incomes below $\$ 25000$, though the distributions were relatively divided within other income categories. Most women in the sample were employed $(63.7 \%)$, did not own homes $(52.9 \%)$, and were more likely to reside in the southern region $(54.0 \%)$ of the country. A majority $(93.8 \%)$ of women self-identified as African-American (table 1).

\section{Prevalence of mental health conditions of all US Black women}

Illustrated in table 2, there were relatively high rates of any mood disorder (16.7\%), major depressive episode $(14.6 \%)$, anxiety $(23.7 \%)$ and post-traumatic stress disorder $(12.0 \%)$ and any overall mental disorder $(39.9 \%)$.

Significantly higher rates of lifetime disorders were found for African-American women compared to Caribbean Black women. These differences were specifically found for any anxiety disorder $(24.1 \%$ vs $17.5 \%$, $\mathrm{p}<0.05)$, post-traumatic stress disorder $(12.3 \%$ vs $8.5 \%$, $\mathrm{p}<0.05)$, and any substance disorder $(6.3$ vs $2.8 \%$, $\mathrm{p}<0.01$ ), alcohol abuse $5.2 \%$ vs $2.4 \%, \mathrm{p}<0.01$ ), suicide attempts $(5.0 \%$ vs $2.7 \%, \mathrm{p}<0.05)$ and any overall disorder $(40.3 \%$ vs $33.5 \%, \mathrm{p}<0.05)$.

\section{Multivariate analysis of factors associated with mental health conditions \\ Anxiety disorder}

Age was associated with anxiety disorder for the total US Black women sample. Women aged 65 years and above $(\mathrm{AOR}=0.335, \mathrm{p}<0.01)$ and those between the age of 50 $64(\mathrm{AOR}=0.579, \mathrm{p}<0.05)$ were less likely to meet criteria for anxiety compared to younger women (see table 3). High school graduated women were also less likely
$(\mathrm{AOR}=0.647, \mathrm{p}<0.01)$ to have anxiety. Conversely, women experiencing everyday discrimination were just over twice as likely (AOR=2.08, $\mathrm{p}<0.01$ ) to have anxiety than women who did not have such experiences. Increased likelihood for anxiety was also found for severely abused women. Severely physically abused women were almost two and a half times more likely $(\mathrm{AOR}=2.46, \mathrm{p}<0.001)$ to have an anxiety disorder than those reporting not being subjected to severe physical IPV.

\section{Mood disorder}

Multivariate analysis further revealed that compared to the younger women (18-24), women between the ages of 50-64 $(\mathrm{AOR}=0.603, \mathrm{p}<0.05)$ and those over the age of 65 were less likely $(\mathrm{AOR}=0.219, \mathrm{p}<0.001)$ to have a mood

Table 1 Characteristics of all US Black women, 2001-2003 NSAL ( $\mathrm{N}=3277)$

\begin{tabular}{|c|c|c|}
\hline Characteristics & $\mathbf{N}$ & Per cen \\
\hline \multicolumn{3}{|l|}{ Age } \\
\hline $18-24$ & 440 & 15.9 \\
\hline $25-34$ & 755 & 20.5 \\
\hline $35-49$ & 1124 & 33.1 \\
\hline $50-64$ & 575 & 18.2 \\
\hline$>65$ & 383 & 12.3 \\
\hline \multicolumn{3}{|l|}{ Marital status } \\
\hline Married & 802 & 27.4 \\
\hline Partnered & 223 & 8.4 \\
\hline Separated-divorced & 759 & 20.3 \\
\hline Widowed & 360 & 11.5 \\
\hline Never married & 1121 & 32.4 \\
\hline \multicolumn{3}{|l|}{ Education } \\
\hline Less than high school & 772 & 24.7 \\
\hline High school graduate & 1152 & 36.2 \\
\hline Some college & 799 & 24.9 \\
\hline College & 554 & 14.2 \\
\hline \multicolumn{3}{|l|}{ Household income } \\
\hline$<\$ 25000$ & 1706 & 50.6 \\
\hline$\$ 25000-\$ 34999$ & 502 & 14.4 \\
\hline$\$ 35000-\$ 49999$ & 461 & 14.4 \\
\hline$\$ 50000-\$ 74999$ & 360 & 11.9 \\
\hline$>\$ 75000$ & 248 & 8.8 \\
\hline \multicolumn{3}{|l|}{ Occupational status } \\
\hline Employed & 2140 & 63.7 \\
\hline Not employed & 361 & 11.1 \\
\hline Not in the labour force & 771 & 25.2 \\
\hline \multicolumn{3}{|l|}{ Home ownership } \\
\hline Does not own & 1854 & 52.9 \\
\hline Own & 1423 & 47.2 \\
\hline \multicolumn{3}{|l|}{ Region } \\
\hline Northwest & 977 & 18.8 \\
\hline Midwest & 400 & 18.9 \\
\hline South & 1756 & 54.0 \\
\hline West & 144 & 8.3 \\
\hline \multicolumn{3}{|l|}{ Ethnicity } \\
\hline African-American & 2299 & 93.8 \\
\hline Caribbean Black & 978 & 6.2 \\
\hline
\end{tabular}

Statistics are weighted.

NSAL, National Survey of American Life. 
Table 2 Lifetime prevalence of mental disorders among US Black women by race/ethnicity, 2001-2003 NSAL

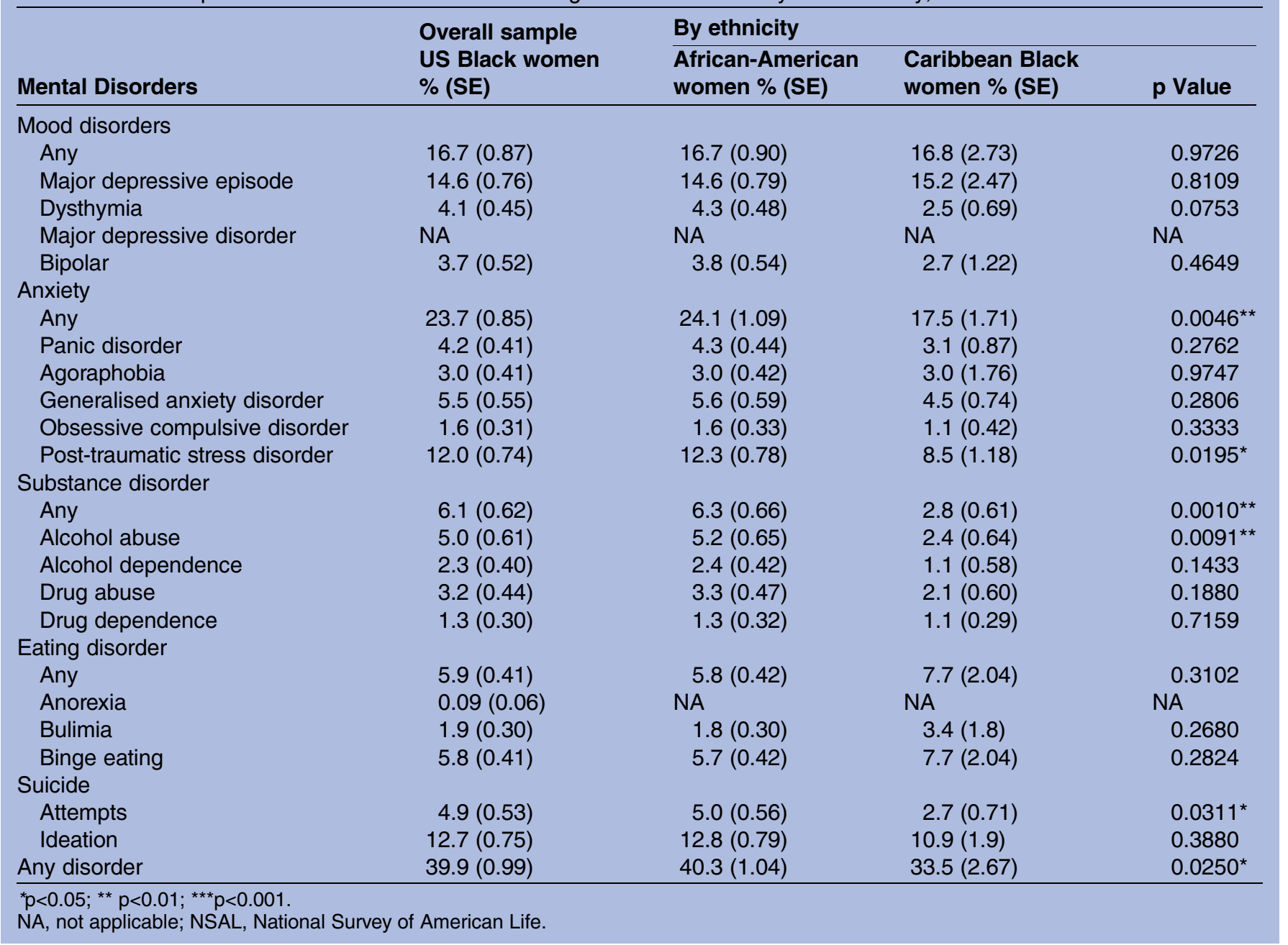

disorder (see table 4). The odds for mood disorder, however, increased $(\mathrm{AOR}=1.19, \mathrm{p}<0.01)$ with drug problems in the neighbourhood. Additionally, severely physically abused women were almost two and a half times more likely $(\mathrm{AOR}=2.41, \mathrm{p}<0.001)$ to have a mood disorder compared to non-severely physically abused women.

\section{Substance disorder}

The analysis revealed that high school educated women were less likely than lower educated women $(\mathrm{AOR}=0.493, \mathrm{p}<0.05)$ to have a substance disorder (see table 5). Also, Caribbean Black women were less likely $(\mathrm{AOR}=0.466, \mathrm{p}<0.01)$ to meet criteria for a substance disorder compared to African-American women. Similar results were found for women with incomes between $\$ 50000$ and \$74999, who were also less likely $(\mathrm{AOR}=0.338, \mathrm{p}<0.05)$ to have a substance disorder. The odds conversely increased for substance disorder by over one and a half times $(\mathrm{AOR}=1.67, \mathrm{p}<.05)$ for women with incomes between $\$ 25000$ and $\$ 34999$. Furthermore, there was a greater likelihood for substance disorder among women between the ages of 35 and 49 by over two times $(\mathrm{AOR}=2.15, \mathrm{p}<0.05)$ compared to younger women, as well as for women whose neighbourhoods had drug problem issues $(\mathrm{AOR}=1.37, \mathrm{p}<0.01)$. Finally, substance disorder significantly increased by three and a half times $(\mathrm{AOR}=3.52, \mathrm{p}<0.001)$ for women who experienced severe physical IPV compared to non-victims of severe physical IPV.

\section{Eating disorder}

Results of the study also revealed that there were lower odds for an eating disorder among college-educated women $(\mathrm{AOR}=0.360, \mathrm{p}<0.05)$ compared to women with less than a high school education (see table 6). On the other hand, the odds for having an eating disorder increased by more than two and a half times $(\mathrm{AOR}=2.69, \mathrm{p}<0.01)$ when Black women experienced everyday discrimination. Also, severely physically abused women were over one and a half times more likely $(\mathrm{AOR}=1.68, \mathrm{p}<0.05)$ to have an eating disorder than non-abused women. 
Table 3 Lifetime anxiety disorder among all Black women by, 2001-2003 NSAL

\begin{tabular}{|c|c|c|c|}
\hline Characteristics & Block 1 & Block 2 & Block 3 \\
\hline \multicolumn{4}{|l|}{ Age } \\
\hline $18-24$ & Ref & Ref & Ref \\
\hline 25-34 & 0.750 (0.532 to 1.06$)$ & $0.767(0.533$ to 1.10$)$ & $0.690(0.474$ to 1.00$)$ \\
\hline $35-49$ & 0.961 (0.678 to 1.36$)$ & 0.996 (0.698 to 1.42$)$ & 0.885 (0.618 to 1.27$)$ \\
\hline $50-64$ & $0.660(0.420$ to 1.03$)$ & $0.653(0.416$ to 1.03$)$ & $0.579(0.369 \text { to } 0.907)^{\star}$ \\
\hline$>65$ & $0.276(0.142 \text { to } 0.535)^{\star \star *}$ & $0.319(0.155 \text { to } 0.655)^{\star *}$ & $0.335(0.166 \text { to } 0.675)^{\star *}$ \\
\hline \multicolumn{4}{|l|}{ Marital status } \\
\hline Married & Ref & Ref & Ref \\
\hline Partnered & $1.58(0.980$ to 2.54$)$ & $1.38(0.835$ to 2.28$)$ & $1.33(0.793$ to 2.24$)$ \\
\hline Separated-divorced & $1.46(1.04 \text { to } 2.04)^{*}$ & $1.31(0.903$ to 1.89$)$ & $1.16(0.801$ to 1.67$)$ \\
\hline Widowed & $1.65(1.01 \text { to } 2.70)^{*}$ & 1.73 (0.989 to 3.03 ) & 1.67 (0.939 to 2.96$)$ \\
\hline Never married & 1.29 (0.867 to 1.92$)$ & $1.23(0.818$ to 1.85$)$ & $1.24(0.822$ to 1.86$)$ \\
\hline \multicolumn{4}{|l|}{ Education } \\
\hline Less than high school & Ref & Ref & Ref \\
\hline High school graduate & $0.613(0.474 \text { to } 0.791)^{\star \star \star}$ & $0.601(0.468 \text { to } 0.722)^{\star \star \star}$ & $0.647(0.498 \text { to } 0.841)^{\star \star}$ \\
\hline Some college & $0.677(0.461 \text { to } 0.995)^{\star}$ & $0.685(0.462$ to 1.01$)$ & 0.719 (0.485 to 1.07$)$ \\
\hline College & $0.712(0.443$ to 1.14$)$ & $0.732(0.449$ to 1.19$)$ & $0.787(0.483$ to 1.28$)$ \\
\hline \multicolumn{4}{|l|}{ Income } \\
\hline$<\$ 25000$ & Ref & Ref & Ref \\
\hline$\$ 25000-\$ 34999$ & $0.970(0.681$ to 1.38$)$ & $1.07(0.772$ to 1.48$)$ & $1.15(0.822$ to 1.61$)$ \\
\hline$\$ 35000-\$ 49999$ & 0.756 (0.511 to 1.12$)$ & 0.804 (0.547 to 1.18$)$ & $0.860(0.577$ to 1.28$)$ \\
\hline$\$ 50000-\$ 74999$ & 0.715 (0.478 to 1.07$)$ & 0.754 (0.505 to 1.13$)$ & 0.788 (0.527 to 1.18$)$ \\
\hline$>\$ 75000$ & $1.15(0.722$ to 1.83$)$ & $1.20(0.734$ to 1.97$)$ & $1.32(0.802$ to 2.17$)$ \\
\hline \multicolumn{4}{|l|}{ Occupational status } \\
\hline Employed & Ref & Ref & Ref \\
\hline Not employed & 1.07 (0.781 to 1.48$)$ & $1.11(0.806$ to 1.54$)$ & 1.07 (0.769 to 1.49$)$ \\
\hline Not in the labour force & $1.11(0.820$ to 1.51$)$ & $1.14(0.826$ to 1.58$)$ & $1.12(0.795$ to 1.58$)$ \\
\hline \multicolumn{4}{|l|}{ Ethnicity } \\
\hline African-American & Ref & Ref & Ref \\
\hline Caribbean Black & $0.671(0.505 \text { to } 0.890)^{\star *}$ & $0.706(0.511 \text { to } 0.976)^{*}$ & 0.735 (0.536 to 1.01$)$ \\
\hline \multicolumn{4}{|l|}{ Discrimination } \\
\hline No & & Ref & Ref \\
\hline Yes & & $2.28(1.34 \text { to } 3.88)^{\star \star}$ & $2.08(1.23 \text { to } 3.51)^{\star *}$ \\
\hline Neighbourhood crime problem & & 1.04 (0.924 to 1.18$)$ & 1.03 (0.912 to 1.15$)$ \\
\hline Neighbourhood drug problem & & $1.16(0.991$ to 1.35$)$ & 1.15 (0.986 to 1.35$)$ \\
\hline \multicolumn{4}{|l|}{ Severe IPV } \\
\hline No & & & Ref \\
\hline Yes & & & $2.46(1.92 \text { to } 3.15)^{\star \star \star}$ \\
\hline Model F statistic, $p$ value & $F=3.68, p<0.00$ & $F=4.12, p<=0.00$ & $F=9.49, p<=0.00$ \\
\hline
\end{tabular}

Suicide ideation

Age, education and severe physical IPV were associated with suicide ideation among all US Black women (see table 7). Specifically, women between the ages of $50-64(\mathrm{AOR}=0.483, \mathrm{p}<0.05)$ and 65 years and above $(\mathrm{AOR}=0.163, \mathrm{p}<0.001)$ were less likely to have ideation compared to younger women (eg, 18-24). Similar findings were observed for high school graduates $(\mathrm{AOR}=0.707, \mathrm{p}<0.05)$ and college educated women $(\mathrm{AOR}=0.470, \mathrm{p}<0.01)$, who were also less likely to have ideation about suicide. By contrast, the likelihood for suicide ideation increased over two and a half times $(A O R=2.65, p<0.001)$ for victims of severe physical IPV compared to non-victims of severe physical abuse.
Any disorder

Women between the ages of 50 and 64 (AOR=0.351, $\mathrm{p}<0.001)$ and over 65 years of age $(\mathrm{AOR}=0.265, \mathrm{p}<0.001)$ were less likely to meet criteria for any disorder compared to younger women (see table 8). In addition, women with only a high school education $(\mathrm{AOR}=0.649$, $\mathrm{p}<0.01)$ were less likely to have any disorder. The odds for any disorder were further reduced for Caribbean women $\quad(\mathrm{AOR}=0.758, \mathrm{p}<0.01) \quad$ compared to their African-American counterparts. However, there was a greater likelihood for any disorder among women by marital status. Specifically, as compared to married women the likelihood for any disorder increased by more than one and a half times for separated or divorced women $(\mathrm{AOR}=1.76, \mathrm{p}<0.01)$, widowed women 
Table 4 Lifetime mood disorder among all Black women by, 2001-2003 NSAL

\begin{tabular}{|c|c|c|c|}
\hline Characteristics & Block 1 & Block 2 & Block 3 \\
\hline \multicolumn{4}{|l|}{ Age } \\
\hline $18-24$ & Ref & Ref & Ref \\
\hline $25-34$ & $0.898(0.620$ to 1.30$)$ & 0.960 (0.665 to 1.38$)$ & $0.877(0.590$ to 1.30$)$ \\
\hline $35-49$ & $0.873(0.567$ to 1.35$)$ & 0.938 (0.606 to 1.45$)$ & $0.828(0.520$ to 1.32$)$ \\
\hline $50-64$ & $0.640(0.420 \text { to } 0.976)^{\star}$ & 0.683 (0.455 to 1.03$)$ & $0.603(0.393 \text { to } 923)^{*}$ \\
\hline$>65$ & $0.175(0.076 \text { to } 0.402)^{\star \star \star}$ & $0.209(0.092 \text { to } 0.474)^{\star \star \star}$ & $0.219(0.098 \text { to } 0.489)^{\star * *}$ \\
\hline \multicolumn{4}{|l|}{ Marital status } \\
\hline Married & Ref & Ref & Ref \\
\hline Partnered & 1.48 (0.784 to 2.79$)$ & 1.28 (0.638 to 2.57$)$ & 1.24 (0.624 to 2.45$)$ \\
\hline Separated-divorced & $1.77(1.24 \text { to } 2.53)^{\star \star}$ & $1.60(1.09 \text { to } 2.34)^{*}$ & $1.44(0.968$ to 2.16$)$ \\
\hline Widowed & 1.65 (0.829 to 3.29$)$ & 1.69 (0.849 to 3.36$)$ & 1.63 (0.784 to 3.37$)$ \\
\hline Never married & $1.26(0.824$ to 1.93$)$ & 1.24 (0.794 to 1.95$)$ & $1.25(0.794$ to 1.97$)$ \\
\hline \multicolumn{4}{|l|}{ Education } \\
\hline Less than high school & Ref & Ref & Ref \\
\hline High school graduate & $0.705(0.520 \text { to } 0.955)^{*}$ & $0.708(0.518 \text { to } 0.967)^{\star}$ & 0.761 (0.544 to 1.06$)$ \\
\hline Some college & 0.895 (0.593 to 1.35$)$ & 0.937 (0.623 to 1.41$)$ & 0.987 (0.648 to 1.50$)$ \\
\hline College & $1.00(0.589$ to 1.71$)$ & 1.09 (0.633 to 1.88$)$ & $1.18(0.679$ to 2.05$)$ \\
\hline \multicolumn{4}{|l|}{ Income } \\
\hline$<\$ 25000$ & Ref & Ref & Ref \\
\hline$\$ 25000-\$ 34999$ & 1.09 (0.753 to 1.58$)$ & $1.14(0.786$ to 1.65$)$ & $1.22(0.835$ to 1.78$)$ \\
\hline$\$ 35000-\$ 49999$ & $0.933(0.583$ to 1.49$)$ & 0.938 (0.596 to 1.47$)$ & $1.00(0.629$ to 1.60$)$ \\
\hline$\$ 50000-\$ 74999$ & 0.999 (0.630 to 1.58$)$ & 0.928 (0.568 to 1.51$)$ & 0.971 ( 0.616 to 1.53$)$ \\
\hline$>\$ 75000$ & 1.39 (0.746 to 2.57$)$ & $1.39(0.728$ to 2.66$)$ & $1.53(0.794$ to 2.93$)$ \\
\hline \multicolumn{4}{|l|}{ Occupational status } \\
\hline Employed & Ref & Ref & Ref \\
\hline Not employed & 1.07 (0.731 to 1.55$)$ & 1.03 (0.699 to 1.52$)$ & 0.975 (0.651 to 1.46$)$ \\
\hline Not in the labour force & $1.11(0.776$ to 1.60$)$ & $1.16(0.814$ to 1.64$)$ & $1.12(0.785$ to 1.60$)$ \\
\hline \multicolumn{4}{|l|}{ Ethnicity } \\
\hline African-American & Ref & Ref & Ref \\
\hline Caribbean Black & 0.963 (0.627 to 1.48$)$ & 1.00 (0.658 to 1.52$)$ & 1.05 (0.683 to 1.62$)$ \\
\hline \multicolumn{4}{|l|}{ Discrimination } \\
\hline No & & Ref & Ref \\
\hline Yes & & 1.51 (0.798 to 2.87$)$ & $1.37(0.722$ to 2.59$)$ \\
\hline Neighbourhood crime problem & & 0.976 (0.853 to 1.12$)$ & 0.963 (0.846 to 1.09$)$ \\
\hline Neighbourhood drug problem & & $1.20(1.04 \text { to } 1.37)^{\star \star}$ & $1.19(1.04 \text { to } 1.36)^{\star}$ \\
\hline \multicolumn{4}{|l|}{ Severe IPV } \\
\hline No & & & Ref \\
\hline Yes & & & $2.41(1.81 \text { to } 3.21)^{\star \star \star}$ \\
\hline Model F statistic, $p$ value & $F=2.81, p<=0.00$ & $F=3.02, p<=0.00$ & $F=7.50, p<=0.00$ \\
\hline
\end{tabular}

$(\mathrm{AOR}=1.64, \mathrm{p}<0.05)$, and for women who had never married (AOR 1.57, $\mathrm{p}<$. 01). Women's likelihood for any disorder $(\mathrm{AOR}=1.18, \mathrm{p}<0.05)$ further increased with drug problems in the neighbourhood. Additionally, women in the study were about twice as likely $(\mathrm{AOR}=2.18, \mathrm{p}<0.001)$ to meet criteria for any disorder when they experienced discrimination. Also, severely physically abused women were over three times (AOR=3.11, p<0.001) more likely than non-victims of severe physical abuse to meet criteria for any disorder.

\section{DISCUSSION}

In this study, we explored rates of mental disorders among US Black women (African-American and
Caribbean Blacks) in the USA, with a focus on social and other contextual factors including neighbourhood characteristics, perceived discrimination and IPV. We found generally high rates of any anxiety disorder $(23.7 \%)$ and mood disorder $(16.7 \%)$ among all US Black women, relative to other mental disorders in this population. High rates of suicide ideation were also noted $(12.7 \%)$. Importantly, lifetime rates of mental disorder among Black women in this study were slightly lower than estimates from the general population. ${ }^{34}$

The results of the study also provide some support for the idea that immigrant groups may have more favourable health conditions than non-immigrants. This was evident across mental health conditions (with the exception of eating disorders), noticeably lower rates of post- 
Table 5 Lifetime substance abuse disorder among all Black women by, 2001-2003 NSAL

\begin{tabular}{|c|c|c|c|}
\hline Characteristics & Block 1 & Block 2 & Block 3 \\
\hline \multicolumn{4}{|l|}{ Age } \\
\hline $18-24$ & Ref & Ref & Ref \\
\hline $25-34$ & 1.30 (0.606 to 2.79$)$ & 1.20 (0.545 to 2.63$)$ & 0.978 (0.464 to 2.06$)$ \\
\hline $35-49$ & $2.53(1.27 \text { to } 5.03)^{\star \star}$ & $2.69(1.33 \text { to } 5.47)^{\star \star}$ & $2.15(1.06 \text { to } 4.37)^{*}$ \\
\hline $50-64$ & $1.58(0.657$ to 3.80$)$ & $1.63(0.661$ to 4.01$)$ & 1.26 (0.529 to 3.02$)$ \\
\hline$>65$ & $0.613(0.167$ to 2.25$)$ & $0.708(0.188$ to 2.66$)$ & 0.756 (0.199 to 2.87$)$ \\
\hline \multicolumn{4}{|l|}{ Marital status } \\
\hline Married & Ref & Ref & Ref \\
\hline Partnered & 1.55 (0.672 to 3.59$)$ & $1.26(0.510$ to 3.11$)$ & $1.12(0.462$ to 2.72$)$ \\
\hline Separated-divorced & 1.11 (0.645 to 1.92$)$ & $0.940(0.523$ to 1.69$)$ & $0.775(0.410$ to 1.46$)$ \\
\hline Widowed & 1.13 (0.463 to 2.78$)$ & 1.16 (0.437 to 3.09$)$ & $1.06(0.388$ to 2.87$)$ \\
\hline Never married & $1.66(0.881$ to 3.15$)$ & $1.50(0.773$ to 2.91$)$ & 1.48 (0.759 to 2.88$)$ \\
\hline \multicolumn{4}{|l|}{ Education } \\
\hline Less than high school & Ref & Ref & Ref \\
\hline High school graduate & $0.425(0.245 \text { to } 0.737)^{\star \star}$ & $0.452(0.262 \text { to } 0.782)^{\star}$ & $0.493(0.280 \text { to } 0.866)^{*}$ \\
\hline Some college & $0.756(0.427$ to 1.34$)$ & 0.784 (0.434 to 1.42$)$ & 0.820 (0.456 to 1.47$)$ \\
\hline College & $0.383(0.154 \text { to } 0.953)^{*}$ & $0.428(0.165$ to 1.11$)$ & $0.469(0.185$ to 1.19$)$ \\
\hline \multicolumn{4}{|l|}{ Income } \\
\hline$<\$ 25000$ & Ref & Ref & Ref \\
\hline$\$ 25000-\$ 34999$ & $1.22(0.750$ to 2.00$)$ & $1.44(0.910$ to 2.29$)$ & $1.67(1.05 \text { to } 2.66)^{\star}$ \\
\hline$\$ 35000-\$ 49999$ & $0.439(0.191 \text { to } 1.01)^{\star}$ & $0.450(0.212$ to 1.80$)$ & $0.560(0.225$ to 1.39$)$ \\
\hline$\$ 50000-\$ 74999$ & $0.252(0.105 \text { to } 0.605)^{\star *}$ & $0.309(0.127 \text { to } 7.53)^{\star *}$ & $0.338(0.135 \text { to } 0.846)^{*}$ \\
\hline$>\$ 75000$ & $0.740(0.349$ to 1.57$)$ & 0.893 (0.439 to 1.82$)$ & 1.09 (0.549 to 2.19$)$ \\
\hline \multicolumn{4}{|l|}{ Occupational status } \\
\hline Employed & Ref & Ref & Ref \\
\hline Not employed & 1.08 (0.564 to 2.05$)$ & $0.971(0.523$ to 1.80$)$ & 0.888 (0.465 to 1.70$)$ \\
\hline Not in the labour force & 1.19 (0.654 to 2.18$)$ & $1.12(0.607$ to 2.08$)$ & $1.05(0.550$ to 2.01$)$ \\
\hline \multicolumn{4}{|l|}{ Ethnicity } \\
\hline African-American & Ref & Ref & Ref \\
\hline Caribbean Black & $0.467(0.265 \text { to } 0.820)^{\star *}$ & $0.455(0.246 \text { to } 0.842)^{\star *}$ & $0.466(0.255 \text { to } 0.851)^{\star \star}$ \\
\hline \multicolumn{4}{|l|}{ Discrimination } \\
\hline No & & Ref & Ref \\
\hline Yes & & $1.54(0.654$ to 3.61$)$ & $1.24(0.531$ to 2.91$)$ \\
\hline Neighbourhood crime problem & & $1.13(0.954$ to 1.34$)$ & $1.10(0.906$ to 1.34$)$ \\
\hline Neighbourhood drug problem & & $1.37(1.12 \text { to } 1.68)^{\star \star}$ & $1.37(1.11 \text { to } 1.69)^{\star *}$ \\
\hline \multicolumn{4}{|l|}{ Severe IPV } \\
\hline No & & & Ref \\
\hline Yes & & & $3.52(2.21 \text { to } 5.60)^{\star \star \star}$ \\
\hline Model F statistic, $p$ value & $F=4.77, p<=0.00$ & $F=8.24, p<=0.00$ & $F=15.96, p<=0.00$ \\
\hline
\end{tabular}

traumatic stress disorder, alcohol abuse disorder and suicide attempts were found for Caribbean Black women compared to African-American women. These results may be reflective of reduced exposure to stressful environmental conditions and enduring Caribbean cultural attitudes that are less accepting of certain behaviours (eg, alcohol abuse, suicide) detrimental to health for women within this population. ${ }^{35}$ Perceived discrimination was associated with higher odds of any anxiety disorder, eating disorder and any mental disorder. We also found neighbourhood characteristics (specifically, the perceived presence of neighbourhood drug problems) to be associated with any mood disorder, any substance disorder, and any overall mental disorder. As noted in prior studies, these social and environmental stressors can adversely impact the health and well-being of women. ${ }^{36}$
Despite these important contributions to Black women's health status, severe physical IPV was associated with negative health conditions, such as anxiety disorders, mood disorders, substance disorders, eating disorders, and suicide ideation, consistent with other studies. ${ }^{25} 2628$ Moreover, across various health conditions, age was an important contributor to women's health. The findings revealed that as US Black women aged they were less prone to mental conditions, such as anxiety, mood, and any mental disorders and suicide ideation. ${ }^{37}{ }^{38}$ US Black women in the study also tended to abuse substances at an earlier age (eg, 25-34), which has been supported by previous studies. ${ }^{39}$ We did find, however, that separated or divorced, widowed and never married women were more likely than married women to meet criteria for any mental condition. 
Table 6 Lifetime eating disorder among Black women by, 2001-2003 NSAL

\begin{tabular}{|c|c|c|c|}
\hline Characteristics & Block 1 & Block 2 & Block 3 \\
\hline \multicolumn{4}{|l|}{ Age } \\
\hline $18-24$ & Ref & Ref & Ref \\
\hline $25-34$ & $0.764(0.353$ to 1.65$)$ & $0.756(0.350$ to 1.63$)$ & $0.700(0.328$ to 1.49$)$ \\
\hline $35-49$ & $0.811(0.370$ to 1.77$)$ & 0.807 (0.364 to 1.79$)$ & $0.726(0.321$ to 1.64$)$ \\
\hline $50-64$ & $0.611(0.255$ to 1.46$)$ & 0.697 (0.281 to 1.73$)$ & $0.631(0.252$ to 1.58$)$ \\
\hline$>65$ & 0.691 (0.263 to 1.82$)$ & 0.981 (0.380 to 2.53$)$ & 0.995 (0.385 to 2.57$)$ \\
\hline \multicolumn{4}{|l|}{ Marital status } \\
\hline Married & Ref & Ref & Ref \\
\hline Partnered & 0.894 (0.353 to 2.27$)$ & $0.771(0.280$ to 2.11$)$ & $0.742(0.266$ to 2.07$)$ \\
\hline Separated-divorced & $1.55(0.850$ to 2.84$)$ & 1.29 (0.687 to 2.42$)$ & $1.21(0.629$ to 2.34$)$ \\
\hline Widowed & $0.594(0.214$ to 1.65$)$ & $0.561(0.207$ to 1.52$)$ & $0.541(0.200$ to 1.47$)$ \\
\hline Never married & $1.02(0.527$ to 1.96$)$ & 0.911 (0.481 to 1.72$)$ & $0.884(0.473$ to 1.65$)$ \\
\hline \multicolumn{4}{|l|}{ Education } \\
\hline Less than high school & Ref & Ref & Ref \\
\hline High school graduate & $1.22(0.759$ to 1.97$)$ & $1.24(0.756$ to 2.02$)$ & 1.27 (0.771 to 2.10$)$ \\
\hline Some college & $0.998(0.564$ to 1.77$)$ & 1.07 (0.583 to 1.95$)$ & $1.08(0.596$ to 1.97$)$ \\
\hline College & $0.327(0.130 \text { to } 0.825)^{\star}$ & $0.345(0.131 \text { to } 0.908)^{*}$ & $0.360(0.135 \text { to } 0.956)^{*}$ \\
\hline \multicolumn{4}{|l|}{ Income } \\
\hline$<\$ 25000$ & Ref & Ref & Ref \\
\hline$\$ 25000-\$ 34999$ & $0.611(0.296$ to 1.26$)$ & $0.670(0.307$ to 1.47$)$ & 0.703 (0.319 to 1.55$)$ \\
\hline$\$ 35000-\$ 49999$ & $0.401(0.178 \text { to } 0.900)^{*}$ & $0.421(0.183 \text { to } 0.972)^{*}$ & $0.446(0.191$ to 1.04$)$ \\
\hline$\$ 50000-\$ 74999$ & $0.542(0.222$ to 1.32$)$ & $0.560(0.207$ to 1.51$)$ & $0.581(0.214$ to 1.58$)$ \\
\hline$>\$ 75000$ & 0.649 (0.187 to 2.25$)$ & 0.660 (0.180 to 2.42$)$ & 0.698 (0.189 to 2.58$)$ \\
\hline \multicolumn{4}{|l|}{ Occupational status } \\
\hline Employed & Ref & Ref & Ref \\
\hline Not employed & $1.15(0.636$ to 2.06$)$ & $1.16(0.645$ to 2.07$)$ & $1.12(0.625$ to 2.01$)$ \\
\hline Not in the labour force & $1.14(0.709$ to 1.82$)$ & $1.14(0.686$ to 1.90$)$ & $1.13(0.671$ to 1.90$)$ \\
\hline \multicolumn{4}{|l|}{ Ethnicity } \\
\hline African-American & Ref & Ref & Ref \\
\hline Caribbean Black & $1.51(0.828$ to 2.74$)$ & 1.57 (0.853 to 2.89$)$ & $1.60(0.881$ to 2.92$)$ \\
\hline \multicolumn{4}{|l|}{ Discrimination } \\
\hline No & & Ref & Ref \\
\hline Yes & & $2.81(1.44 \text { to } 5.46)^{\star \star}$ & $2.69(1.38 \text { to } 5.22)^{\star \star}$ \\
\hline Neighbourhood crime Problem & & $1.12(0.893$ to 1.41$)$ & $1.11(0.883$ to 1.40$)$ \\
\hline Neighbourhood drug Problem & & $1.15(0.866$ to 1.52$)$ & $1.14(0.861$ to 1.52$)$ \\
\hline \multicolumn{4}{|l|}{ Severe IPV } \\
\hline No & & & Ref \\
\hline Yes & & & $1.68(1.08 \text { to } 2.63)^{\star}$ \\
\hline Model F statistic, $p$ value & $\mathrm{F}=2.92, \mathrm{p}<=0.00$ & $F=4.25, p<=0.00$ & $\mathrm{~F}=3.73, \mathrm{p}<=0.00$ \\
\hline
\end{tabular}

Socioeconomic status had several influences on women's mental health. Consistent with past research, ${ }^{40}$ college educated women were less likely to meet criteria for eating disorders and suicidal ideation. However, in the present study, lower educated women were less likely to develop anxiety, substance use, suicide ideation and any disorder. Increasing substance use was associated with low-income status and was less evident for women within higher income categories.

\section{Limitations and strengths}

Several limitations should be considered when interpreting these findings. First, the study was based on a crosssectional sample. Therefore, causal inferences cannot be made about the factors associated with women's mental health outcomes. The study was also limited to severe physical intimate partner abuse. While physical abuse can be devastating and have immediate consequences to women's health ${ }^{41}$ other forms of trauma (eg, emotional abuse, sexual abuse) that can adversely affect women's health in the short and long term, were not examined. However, recent studies on African-American and Caribbean women find that half of those reporting any abuse reported that it was physical abuse. ${ }^{42}$ Second, the discrimination measures used in the study were not directly tied to the specific racial/ethnic encounters that women may have been referencing. We also did not address any temporal dimensions in the analysis, which may have limited our examination of the effects of social context on the health of immigrant women. Some 
Table 7 Lifetime Suicide Ideation among Black Women by, 2001-2003 NSAL

\begin{tabular}{|c|c|c|c|}
\hline Characteristics & Block 1 & Block 2 & Block 3 \\
\hline \multicolumn{4}{|l|}{ Age } \\
\hline $18-24$ & Ref & Ref & Ref \\
\hline $25-34$ & $0.873(0.591$ to 1.29$)$ & 0.897 (0.607 to 1.32$)$ & $0.789(0.520$ to 1.20$)$ \\
\hline $35-49$ & 0.895 (0.560 to 1.43$)$ & 0.945 (0.597 to 1.50$)$ & 0.830 (0.509 to 1.36$)$ \\
\hline $50-64$ & $0.503(0.282 \text { to } 898)^{\star}$ & $0.558(0.310 \text { to } 1.00)^{*}$ & $0.483(0.257 \text { to } 0.909)^{*}$ \\
\hline$>65$ & $0.120(0.049 \text { to } 0.295)^{\star * *}$ & $0.153(0.062 \text { to } 0.381)^{\star * *}$ & $0.163(0.065 \text { to } 409)^{\star \star * *}$ \\
\hline \multicolumn{4}{|l|}{ Marital status } \\
\hline Married & Ref & Ref & Ref \\
\hline Partnered & 1.34 (0.762 to 2.37$)$ & 1.17 (0.644 to 2.13$)$ & $1.12(0.593$ to 2.13$)$ \\
\hline Separated-divorced & $1.19(0.723$ to 1.95$)$ & $1.10(0.657$ to 1.83$)$ & 0.925 (0.542 to 1.58$)$ \\
\hline Widowed & 1.19 (0.664 to 2.13$)$ & 1.22 (0.653 to 2.29$)$ & 1.15 (0.621 to 2.12$)$ \\
\hline Never married & $1.12(0.719$ to 1.76$)$ & $1.09(0.680$ to 1.74$)$ & 1.09 (0.688 to 1.72$)$ \\
\hline \multicolumn{4}{|l|}{ Education } \\
\hline Less than high school & Ref & Ref & Ref \\
\hline High school graduate & $0.654(0.452 \text { to } 0.946)^{*}$ & $0.641(0.452 \text { to } 0.909)^{\star *}$ & $0.707(0.498 \text { to } 1.00)^{\star}$ \\
\hline Some college & $0.644(0.421 \text { to } 0.986)^{\star}$ & $0.624(0.414 \text { to } 0.941)^{*}$ & 0.665 (0.431 to 1.03$)$ \\
\hline College & $0.426(0.235 \text { to } 0.773)^{\star *}$ & $0.428(0.242 \text { to } 0.757)^{\star *}$ & $0.470(0.263 \text { to } 0.841)^{\star *}$ \\
\hline \multicolumn{4}{|l|}{ Income } \\
\hline$<\$ 25000$ & Ref & Ref & Ref \\
\hline$\$ 25000-\$ 34999$ & $1.21(0.813$ to 1.81$)$ & 1.31 (8.55 to 2.01$)$ & $1.44(0.922$ to 2.25$)$ \\
\hline$\$ 35000-\$ 49999$ & $1.00(0.686$ to 1.47$)$ & $1.09(0.741$ to 1.60$)$ & $1.20(0.815$ to 1.75$)$ \\
\hline$\$ 50000-\$ 74999$ & 0.718 (0.363 to 1.42$)$ & 0.819 (0.388 to 1.73$)$ & $0.871(0.425$ to 1.78$)$ \\
\hline$>\$ 75000$ & $1.03(0.511$ to 2.09$)$ & $1.14(0.546$ to 2.39$)$ & $1.27(0.596$ to 2.70$)$ \\
\hline \multicolumn{4}{|l|}{ Occupational status } \\
\hline Employed & Ref & Ref & Ref \\
\hline Not employed & $1.44(0.988$ to 2.11$)$ & 1.48 (0.988 to 2.21$)$ & 1.43 (0.958 to 2.15$)$ \\
\hline Not in the labour force & $1.18(0.854$ to 1.63$)$ & $1.17(0.837$ to 1.63$)$ & $1.15(0.811$ to 1.63$)$ \\
\hline \multicolumn{4}{|l|}{ Ethnicity } \\
\hline African-American & Ref & Ref & Ref \\
\hline Caribbean Black & 0.861 (0.555 to 1.34$)$ & 0.909 (0.581 to 1.42$)$ & 0.933 (0.592 to 1.47$)$ \\
\hline \multicolumn{4}{|l|}{ Discrimination } \\
\hline No & & Ref & Ref \\
\hline Yes & & $1.73(1.01 \text { to } 2.96)^{*}$ & $1.54(0.887$ to 2.67$)$ \\
\hline Neighbourhood crime problem & & $1.02(0.866$ to 1.19 & 0.996 (0.851 to 1.17$)$ \\
\hline Neighbourhood drug problem & & $1.19(0.968$ to 1.47$)$ & $1.19(0.969$ to 1.45$)$ \\
\hline \multicolumn{4}{|l|}{ Severe IPV } \\
\hline No & & & Ref \\
\hline Yes & & & $2.65(1.86 \text { to } 3.75)^{\star \star \star}$ \\
\hline Model F statistic, $p$ value & $F=3.31, p<=0.00$ & $F=7.78, p<=0.00$ & $F=14.74, p<=0.00$ \\
\hline
\end{tabular}

studies have found that the health of immigrant groups deteriorate the longer they reside in the USA and this might be true for Caribbean women in this sample. ${ }^{33}$ Finally, the data were collected over a decade ago during a period where social and economic conditions may differ from today.

Nonetheless, the NSAL remains the largest and most detailed nationally representative sample that provides relevant information on the social context of US Blacks and their experiences. It is also the only national sample of Caribbean Blacks residing in the USA. Furthermore, this study is one of very few to provide a comprehensive picture of the potential social-contextual influences on women's mental health status, including neighbourhood characteristics, perceived discrimination and severe physical IPV. We also explored a wide array of outcomes (anxiety, mood, suicidal ideation, and any DSM disorder). Even so, we must be mindful of the complexity of the CIDI questions and differences in cross-cultural and cross-ethnic interpretations of concepts and in expressions of distress that could possibly influence the study findings. ${ }^{33} 4344$

\section{CONCLUSIONS}

This research has implications both at the clinical and community levels. Research from hospital emergency rooms finds relatively high prevalence of IPV among female African-American patients. ${ }^{45}$ Thus, ERs may provide a unique opportunity to screen both for mental health problems (possible main or comorbid presenting systems) and IPV (a potential cause of these symptoms) among African-American and Caribbean Black women. 
Table 8 Any mental disorder among Black women by, 2001-2003 NSAL

\begin{tabular}{|c|c|c|c|}
\hline Characteristics & Block 1 & Block 2 & Block 3 \\
\hline \multicolumn{4}{|l|}{ Age } \\
\hline $18-24$ & Ref & Ref & Ref \\
\hline $25-34$ & $0.863(0.620$ to 1.20$)$ & $0.873(0.624$ to 1.22$)$ & $0.797(0.565$ to 1.12$)$ \\
\hline $35-49$ & $0.769(0.560$ to 1.06$)$ & $0.793(0.569$ to 1.10$)$ & $0.697(0.499 \text { to } 0.975)^{\star}$ \\
\hline $50-64$ & $0.408(0.282 \text { to } 0.590)^{\star * *}$ & $0.409(0.283 \text { to } 0.593)^{\star \star \star}$ & $0.351(0.237 \text { to } 0.520)^{\star \star \star}$ \\
\hline$>65$ & $0.214(0.126 \text { to } 0.364)^{\star \star \star}$ & $0.252(0.147 \text { to } 0.433)^{\star \star \star}$ & $0.265(0.158 \text { to } 0.444)^{\star \star \star}$ \\
\hline \multicolumn{4}{|l|}{ Marital status } \\
\hline Married & Ref & Ref & Ref \\
\hline Partnered & $2.14(1.34 \text { to } 3.40)^{\star \star}$ & $1.72(1.02 \text { to } 2.92)^{\star}$ & $1.68(0.981$ to 2.86$)$ \\
\hline Separate-divorced & $2.56(1.69 \text { to } 3.02)^{\star \star *}$ & $1.97(1.42 \text { to } 2.74)^{\star \star *}$ & $1.76(1.24 \text { to } 2.51)^{\star \star}$ \\
\hline Widowed & $1.63(1.09 \text { to } 2.44)^{\star}$ & $1.70(1.09 \text { to } 2.67)^{*}$ & $1.64(1.04 \text { to } 2.59)^{*}$ \\
\hline Never married & $1.64(1.22 \text { to } 2.22)^{\star \star}$ & $1.54(1.11 \text { to } 2.13)^{\star \star}$ & $1.57(1.15 \text { to } 2.16)^{\star \star}$ \\
\hline \multicolumn{4}{|l|}{ Education } \\
\hline Less than high school & Ref & Ref & Ref \\
\hline High school graduate & $0.599(0.443 \text { to } 0.810)^{\star \star \star}$ & $0.605(0.438 \text { to } 0.835)^{\star \star}$ & $0.649(0.466 \text { to } 0.905)^{\star \star}$ \\
\hline Some college & $0.664(0.436$ to 1.01$)$ & $0.679(0.430$ to 1.07$)$ & $0.715(0.446$ to 1.14$)$ \\
\hline College & $0.698(0.456$ to 1.07$)$ & $0.737(0.472$ to 1.15$)$ & $0.791(0.505$ to 1.24$)$ \\
\hline \multicolumn{4}{|l|}{ Income } \\
\hline$<\$ 25000$ & Ref & Ref & Ref \\
\hline$\$ 25000-\$ 34999$ & $0.872(0.636$ to 1.19$)$ & $0.964(0.709$ to 1.31$)$ & $1.04(0.760$ to 1.41$)$ \\
\hline$\$ 35000-\$ 49999$ & 0.721 (0.507 to 1.02$)$ & $0.766(0.527$ to 1.11$)$ & $0.822(0.558$ to 1.21$)$ \\
\hline$\$ 50000-\$ 74999$ & $0.817(0.535$ to 1.25$)$ & 0.858 (0.559 to 1.32$)$ & $0.895(0.588$ to 1.36$)$ \\
\hline$>\$ 75000$ & $1.23(0.791$ to 1.92$)$ & $1.30(0.803$ to 2.10$)$ & $1.45(0.891$ to 2.37$)$ \\
\hline \multicolumn{4}{|l|}{ Occupational status } \\
\hline Employed & Ref & Ref & Ref \\
\hline Not employed & $1.02(0.722$ to 1.45$)$ & $1.02(0.712$ to 1.45$)$ & $0.961(0.666$ to 1.39$)$ \\
\hline Not in the labour force & $1.09(0.985$ to 1.33$)$ & $1.13(0.926$ to 1.39$)$ & $1.11(0.890$ to 1.39$)$ \\
\hline \multicolumn{4}{|l|}{ Ethnicity } \\
\hline African-American & Ref & Ref & Ref \\
\hline Caribbean Black & $0.719(0.559 \text { to } 0.925)^{*}$ & $0.724(0.579 \text { to } 905)^{\star \star}$ & $0.758(0.610 \text { to } 0.940)^{\star *}$ \\
\hline \multicolumn{4}{|l|}{ Discrimination } \\
\hline No & & Ref & Ref \\
\hline Yes & & $2.37(1.51 \text { to } 3.72)^{\star \star \star}$ & $2.18(1.40 \text { to } 3.40)^{\star \star \star}$ \\
\hline Neighbourhood crime problem & & $1.09(0.976$ to 1.21$)$ & $1.07(0.966$ to 1.19$)$ \\
\hline Neighbourhood drug problem & & $1.18(1.04 \text { to } 1.35)^{\star}$ & $1.18(1.03 \text { to } 1.34)^{\star}$ \\
\hline \multicolumn{4}{|l|}{ Severe IPV } \\
\hline No & & & Ref \\
\hline Yes & & & $3.11(2.48 \text { to } 3.89)^{\star \star \star}$ \\
\hline Model F statistic, $p$ value & $\mathrm{F}=10.01, \mathrm{p}<=0.00$ & $\mathrm{~F}=11.87, \mathrm{p}<=0.00$ & $F=11.99, p<=0.00$ \\
\hline
\end{tabular}

Medical practitioners should be made aware of these (often hidden) issues; moreover, the development and implementation of brief mental health screening tools in the emergency room may be a promising avenue for intervention for any patient experiencing $\mathrm{IPV}^{46}$ Community-based programmes such as The Interconnections Project for African-American women experiencing IPV should also be culturally tailored and then targeted toward their Caribbean counterparts. ${ }^{47}$

This study has identified areas for future exploration. Consistent with past research, this study found negative consequences of IPV for Black women's mental health. ${ }^{22}$ Nonetheless, further exploration is warranted for a clearer understanding of the consequences of violence among black women both long and short term. In addition, research on women's health should include comparative analyses of other ethnic groups (especially African immigrants) within the Black population to further assess the influence of cultural and social context on women's mental health. This much-needed information may have implications for intervention, treatment and the service needs of individual women, who while similar racially, are still culturally and ethnically distinct.

Contributors KKL was the lead author. KKL, RP, DMM, DH, JA and JSJ contributed to the conceptualisation and writing of this manuscript. NM conducted the statistical analyses.

Funding The National Survey of American Life was funded by the National Institute of Mental Health, with supplemental support from the Office of Behavioural and Social Science Research at the National Institutes of Health, and the University of Michigan (grant U01-MH57716).

Competing interests None declared. 
Provenance and peer review Not commissioned; externally peer reviewed.

Data sharing statement No additional data are available.

Human protection Human subjects protocol for the NSAL was obtained through the University of Michigan's institutional review board.

Open Access This is an Open Access article distributed in accordance with the Creative Commons Attribution Non Commercial (CC BY-NC 4.0) license, which permits others to distribute, remix, adapt, build upon this work noncommercially, and license their derivative works on different terms, provided the original work is properly cited and the use is non-commercial. See: http:// creativecommons.org/licenses/by-nc/4.0/

\section{REFERENCES}

1. Williams DR. Racial/ethnic variations in women's health: the social embeddedness of health. Am J Public Health 2002;92:588-97.

2. Taylor SE, Holden KB. The health status of black women. In: Health issues in the black community. San Francisco, CA: John Wiley \& Sons, Ltd, 2009:44-61.

3. Kent MM. Immigration and America's Black Population. Population Reference Bureau. 2007. http://www.prb.org/Publications/Reports/ 2007/blackimmigration.aspx

4. Thomas KJA. A Demographic Profile of Black Caribbean Immigrants in the United States. 2012. http://www.migrationpolicy.org/research/ CBI-demographic-profile-black-caribbean-immigrants (accessed 18 Jul 2015).

5. Breslau J, Kendler KS, Su M, et al. Lifetime risk and persistence of psychiatric disorders across ethnic groups in the United States. Psychol Med 2005;35:317-27.

6. Read JG, Emerson MO. Racial context, black immigration and the $U$. S. Black/white health disparity. Soc Forces 2005;84:181-99.

7. Williams DR, Haile R, González HM, et al. The mental health of Black Caribbean immigrants: results from the National Survey of American Life. Am J Public Health 2007:97:52-9.

8. Sternthal MJ, Slopen N, Williams DR. Racial disparities in health: how much does stress really matter? Bois Rev Soc Sci Res Race 2011;8:95-113.

9. Williams DR. Miles to go before we sleep: racial inequities in health. $J$ Health Soc Behav 2012;53:279-95.

10. Williams DR. Race, socioeconomic status, and health. The added effects of racism and discrimination. Ann N Y Acad Sci 1999;896:173-88.

11. Mays VM, Cochran SD, Barnes NW. Race, race-based discrimination, and health outcomes among African Americans. Annu Rev Psychol 2007;58:201-25.

12. Williams DR, Williams-Morris R. Racism and mental health: the African American experience. Ethn Health 2000;5:243-68.

13. Kessler RC, Mickelson KD, Williams DR. The prevalence, distribution, and mental health correlates of perceived discrimination in the United States. J Health Soc Behav 1999;40:208-30.

14. Hunt MO, Wise LA, Jipguep MC, et al. Neighborhood racia composition and perceptions of racial discrimination: evidence from the Black women's health study. Soc Psychol Q 2007:272-89.

15. Schulz AJ, Gravlee CC, Williams DR, et al. Discrimination, symptoms of depression, and self-rated health among African American women in Detroit: results from a longitudinal analysis. Am J Public Health 2006;96:1265-70.

16. Williams DR, Collins C. Racial residential segregation: a fundamental cause of racial disparities in health. Public Health Rep 2001;116:404-16.

17. Landrine $\mathrm{H}$, Corral I. Separate and unequal: residential segregation and black health disparities. Ethn Dis 2009;19:179-84.

18. Evans GW. The built environment and mental health. $J$ Urban Health 2003;80:536-55.

19. Stockdale SE, Wells KB, Tang L, et al. The importance of social context: neighborhood stressors, stress-buffering mechanisms, and alcohol, drug, and mental health disorders. Soc Sci Med 2007;65:1867-81.

20. Cozier Y, Palmer JR, Horton NJ, et al. Racial discrimination and the incidence of hypertension in US black women. Ann Epidemiol 2006;16:681-7.

21. Brown JR, Hill HM, Lambert SF. Traumatic stress symptoms in women exposed to community and partner violence. $J$ Interpers Violence 2005;20:1478-94

22. Bent-Goodley TB. Health disparities and violence against women why and how cultural and societal influences matter. Trauma Violence Abuse 2007:8:90-104

23. Cunradi CB, Caetano R, Clark C, et al. Neighborhood poverty as a predictor of intimate partner violence among White, Black, and
Hispanic couples in the United States: a multilevel analysis. Ann Epidemiol 2000;10:297-308.

24. Catalano SM, Michael R. Rand M, et al. Female victims of violence. Washington DC: Bureau of Justice Statistics, 2009.

25. Devries KM, Child JC, Bacchus LJ, et al. Intimate partner violence victimization and alcohol consumption in women: a systematic review and meta-analysis. Addiction 2014:109:379-91.

26. Lacey KK, McPherson MD, Samuel PS, et al. The impact of different types of intimate partner violence on the mental and physical health of women in different ethnic groups. $J$ Interpers Violence 2013;28:359-85.

27. Hien D, Ruglass L. Interpersonal partner violence and women in the United States: an overview of prevalence rates, psychiatric correlates and consequences and barriers to help seeking. Int $J$ Law Psychiatry 2009;32:48-55.

28. Dillon G, Hussain R, Loxton D, et al. Mental and physical health and intimate partner violence against women: a review of the literature. Int J Fam Med 2013;2013:e313909.

29. Jackson JS, Neighbors HW, Nesse RM, et al. Methodologica innovations in the National Survey of American Life. Int $J$ Methods Psychiatr Res 2004;13:289-98.

30. Heeringa SG, Wagner J, Torres M, et al. Sample designs and sampling methods for the Collaborative Psychiatric Epidemiology Studies (CPES). Int J Methods Psychiatr Res 2004;13:221-40.

31. Straus MA. Measuring Intrafamily Conflict and Violence: the Conflict Tactics (CT) Scales. J Marriage Fam 1979;41:75-88.

32. Kessler RC, Molnar BE, Feurer ID, et al. Patterns and mental health predictors of domestic violence in the United States: results from the National Comorbidity Survey. Int J Law Psychiatry 2001;24:487-508.

33. Lacey KK, Sears KP, Govia IO, et al. Substance Use, Mental Disorders and Physical Health of Caribbeans at-Home Compared to Those Residing in the United States. Int J Environ Res Public Health 2015;12:710-34.

34. Harvard Medical School. Lifetime prevalence of DSM-IV/WMH-CIDI disorders by sex and cohort. Cambridge, MA: Harvard Medical School. 2007b. http://www.hcp.med.harvard.edu/ncs/ftpdir/NCS-R Lifetime Prevalence Estimates.pdf (accessed 18 Mar 2015).

35. Takeuchi DT, Alegría M, Jackson JS, et al. Immigration and mental health: diverse findings in Asian, black, and Latino Populations. Am J Public Health 2007:97:11-12.

36. Curtis-Boles $\mathrm{H}$, Jenkins-Monroe V. Substance abuse in African American women. J Black Psychol 2000;26:450-69.

37. Joe S, Baser RE, Breeden G, et al. Prevalence of and risk factors for lifetime suicide attempts among blacks in the United States. JAMA 2006:296:2112-23.

38. Himle JA, Baser RE, Taylor RJ, et al. Anxiety disorders among African Americans, blacks of Caribbean descent, and non-Hispanic whites in the United States. J Anxiety Disord 2009;23:578-90.

39. Substance Abuse and Mental Health Administration. Substance Use Among Black Adults, 2010

40. Muntaner C, $\mathrm{Ng} \mathrm{E}$, Vanroelen C, et al. Social stratification, social closure, and social class as determinants of mental health disparities. In: Aneshensel CS, Phelan JC, Bierman A, eds. Handbook of the sociology of mental health. The Netherlands: Springer, 2013:205-27. http://link.springer.com/chapter/10.1007/ 978-94-007-4276-5 11 (accessed 18 Jul 2015).

41. Tjaden $\mathrm{P}$, Thoennes $\overline{\mathrm{N}}$. Extent, nature, and consequences of intimate partner violence: findings from the national violence against women survey. Atlanta, GA: Centers for Disease Control and Prevention, 2000

42. Lucea MB, Stockman JK, Mana-Ay M, et al. Factors influencing resource use by African American and African Caribbean women disclosing intimate partner violence. $J$ Interpers Violence 2013;28:1617-41.

43. Haro JM, Arbabzadeh-Bouchez S, Brugha TS, et al. Concordance of the Composite International Diagnostic Interview Version 3.0 (CIDI 3.0) with standardized clinical assessments in the WHO World Mental Health surveys. Int J Methods Psychiatr Res 2006;15:167-80.

44. Alegria M, Shrout PE, Torres M, et al. Lessons learned from the clinical reappraisal study of the Composite International Diagnostic Interview with Latinos. Int J Methods Psychiatr Res 2009;18:84-95.

45. Houry D, Kemball R, Rhodes KV et al. Intimate partner violence and mental health symptoms in African American female ED patients. Am J Emerg Med 2006;24:444-50.

46. Houry D, Kemball RS, Click LA, et al. Development of a brief mental health screen for intimate partner violence victims in the emergency department. Acad Emerg Med 2007:14:202-9.

47. Nicolaidis C, Wahab S, Trimble J, et al. The Interconnections Project: development and evaluation of a community-based depression program for African American violence survivors. J Gen Intern Med 2013;28:530-8. 